https://helda.helsinki.fi

\title{
Training the generation $Y$ plastic surgeon
}

\section{Koljonen, Virve}

$2020-10$

Koljonen , V \& Lassus , P 2020 , ' Training the generation Y plastic surgeon ' , Journal of

Plastic, Reconstructive \& Aesthetic Surgery , vol. 73 , no. 10 , pp. 1914-1916 . https://doi.org/10.1016/j.bjps.2020.05

http://hdl.handle.net/10138/335332

https://doi.org/10.1016/j.bjps.2020.05.041

cc_by_nc_nd

draft

Downloaded from Helda, University of Helsinki institutional repository.

This is an electronic reprint of the original article.

This reprint may differ from the original in pagination and typographic detail.

Please cite the original version. 


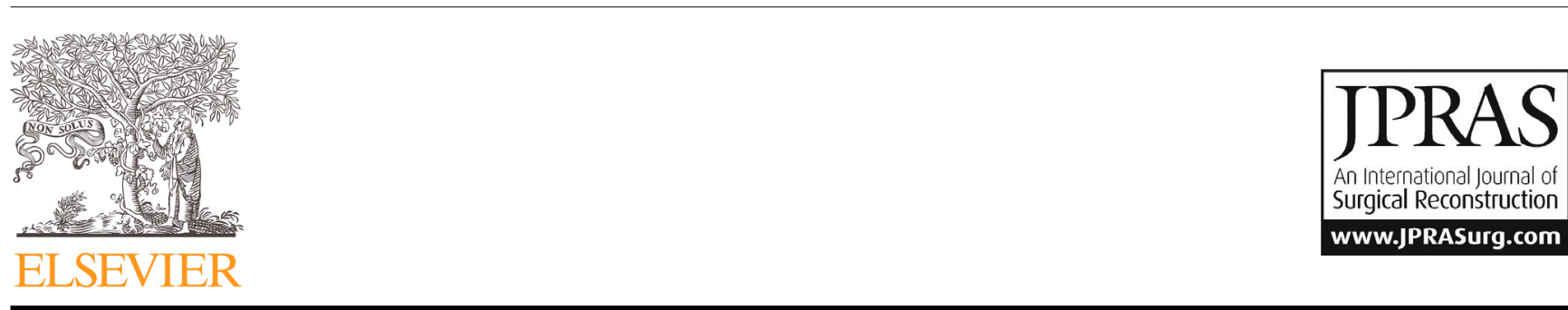

\section{Correspondence and Communications}

\section{Training the generation $Y$ plastic surgeon}

\section{Dear Sir,}

We are two generation $X$ plastic surgeons trained by the previous generation, the Baby Boomers. We are currently practicing during the peak years of our career, and to be quite honest, we consider ourselves to be doing pretty well.

A new generation evolves every 15 to 20 years. It is now our turn to train and support the next generation of plastic surgeons: The Millennials or Generation Y, born between the years 1980-2001. Millennials learn and work in a different manner compared to the previous three generations ${ }^{1}$ and thus it's important to understand their viewpoints in order to help them reach their full potential and avoid intergenerational tensions.

Every generation has its own strengths that reflect the current state and needs of society. This constitutes their advantage with respect to previous generations. Our generation $\mathrm{X}$, is considered independent, industrious, resourceful, innovative risk-takers, decisive problem-solvers, voracious learners, ${ }^{2}$ and we like to regard these as good qualities in plastic surgeons. However, the world is constantly changing. Millennials are the first true digital generation; they have been using internet and social media from an early age and due to this may have short attention spans that has cultivated them to be visual learners and capable of processing and adapting information. ${ }^{1,3,4}$ They are team-oriented and feel comfortable with frequent social interactions. ${ }^{1,5}$ Millennials have also been described to be a "child-centric generation" and they have had very close parental involvement in their childhood. ${ }^{1}$ They are best rewarded with meaningful work. ${ }^{3}$ It is obvious that millennials differ significantly from previous generations by being tech-savvy and visual learners, with short attention span and a desire for feedback. Table 1 provides a crude overview of the dos and don'ts on how to deal with millennials with our proposals. It must be noted that not all individuals fit into this definition, but social anthropologists have found that different generations tend to have a different outlook on core values and attitudes and have different views on life and styles of teaching and learning ${ }^{5}$.

Rather than seeing these differences as obstacles, we feel that the Millennials are an asset to our plastic surgery community. It would be all too easy to teach the Millennials as we were once trained. However, the Millennials learn best when using their natural strengths. We, as the previous generation need to appreciate this and adapt ourselves in order to train them most effectively. By paying attention to our attitudes, we can face together the challenges of the new world. 
Table 1 Short overview of do's and don'ts for training the Millennials, italics our proposals.

\begin{tabular}{|c|c|c|c|}
\hline & How to incorporate into training & Avoid in training & Reference \\
\hline \multirow[t]{3}{*}{ Visual learning } & $\begin{array}{l}\text { Charts, diagrams } \\
\text { Infographics }\end{array}$ & Goals in writing & $\begin{array}{l}\text { Schenarts, P. J. Now arriving: surgical } \\
\text { trainees from generation Z. J Surg } \\
\text { Educ } 2019 .\end{array}$ \\
\hline & Pictures, graphics & $\begin{array}{l}\text { Traditional lectures with } \\
\text { written slides. } \\
\text { Avoid telling what to do }\end{array}$ & $\begin{array}{l}\text { Aaron, M., Levenberg, P. The Millennials } \\
\text { in medicine: tips for teaching the next } \\
\text { generation of physicians. Journal of } \\
\text { Academic Ophthalmology } \\
\text { 2014;7:e017-e020. }\end{array}$ \\
\hline & $\begin{array}{l}\text { Kinesthetic learning, bedside } \\
\text { teaching } \\
\text { More personal involvement in OR } \\
\text { teaching }\end{array}$ & $\begin{array}{l}\text { How I do it } \\
\text { Lectures/monologues }\end{array}$ & $\begin{array}{l}\text { Evans, K. H., Ozdalga, E., Ahuja, N. The } \\
\text { medical education of generation Y. } \\
\text { Acad Psychiatry 2016;40:382-385 }\end{array}$ \\
\hline $\begin{array}{l}\text { Short attention } \\
\text { span }\end{array}$ & Shorter sessions & $\begin{array}{l}\text { Lengthy meetings } \\
\text { lectures } \\
\text { Long conversations } \\
\text { reading long texts }\end{array}$ & $\begin{array}{l}\text { Aaron, M., Levenberg, P. The Millennials } \\
\text { in medicine: tips for teaching the next } \\
\text { generation of physicians. Journal of } \\
\text { Academic Ophthalmology } \\
\text { 2014;7:e017-e020. } \\
\text { Schenarts, P. J. Now Arriving: Surgical } \\
\text { Trainees From Generation Z. J Surg } \\
\text { Educ 2019. }\end{array}$ \\
\hline Tech-savvy & $\begin{array}{l}\text { Incorporate up-to-date technology, } \\
\text { such as online modules and } \\
\text { Podcasts, short video segments like } \\
\text { on YouTube }\end{array}$ & $\begin{array}{l}\text { Less focus on textbooks } \\
\text { and lecture slides }\end{array}$ & $\begin{array}{l}\text { Aaron, M., Levenberg, P. The Millennials } \\
\text { in medicine: tips for teaching the next } \\
\text { generation of physicians. Journal of } \\
\text { Academic Ophthalmology } \\
\text { 2014;7:e017-e020. } \\
\text { Louie, M., Moulder, J. K., Wright, K., } \\
\text { Siedhoff, M. Mentoring Millennials in } \\
\text { surgical education. Curr Opin Obstet } \\
\text { Gynecol 2019;31:279-284. }\end{array}$ \\
\hline Reward & $\begin{array}{l}\text { Provide reasoning for tasks, provide } \\
\text { feedback Regular development } \\
\text { discussion/performance appraisals } \\
\text { Engaging the residents, empowering } \\
\text { them as valued and contributing } \\
\text { members of the team }\end{array}$ & $\begin{array}{l}\text { Do not expect them to } \\
\text { know they are valued }\end{array}$ & $\begin{array}{l}\text { Evans, K. H., Ozdalga, E., Ahuja, N. The } \\
\text { medical education of generation Y. } \\
\text { Acad Psychiatry 2016;40:382-385 } \\
\text { Evans, K. H., Ozdalga, E., Ahuja, N. The } \\
\text { medical education of generation Y. } \\
\text { Acad Psychiatry 2016;40:382-385 }\end{array}$ \\
\hline
\end{tabular}

\section{Declaration of Competing Interest}

Each author declares no financial conflicts of interest regarding the data presented in this manuscript. The funding of this article was from departmental sources only.

\section{Acknowledgments}

We thank Mr. Andrew Lindford for his help in the preparation of the letter.

\section{References}

1. Aaron M, Levenberg P. The Millennials in medicine: tips for teaching the next generation of physicians. J Acad Ophthalmol 2014; 7:e017-ee20.

2. Rohrich RJ. Training the generation $X$ plastic surgeon: dispelling the myths? Plast Reconstr Surg 2001;108:1733-4.
3. Schenarts PJ. Now arriving: surgical trainees from generation $Z$. J Surg Educ 2020;77:246-53.

4. Louie M, Moulder JK, Wright K, Siedhoff M. Mentoring Millennials in surgical education. Curr Opin Obstet Gynecol 2019;31:279-84.

5. Evans KH, Ozdalga E, Ahuja N. The medical education of generation Y. Acad Psychiatry 2016;40:382.

Virve Koljonen

E-mail address: virve.koljonen@hus.fi

Patrik Lassus

Department of Plastic Surgery, University of Helsinki and Helsinki University Hospital, P.O. Box 266, Fl-00029

Helsinki, Finland

(C) 2020 British Association of Plastic, Reconstructive and Aesthetic Surgeons. Published by Elsevier Ltd. All rights reserved.

https://doi.org/10.1016/j.bjps.2020.05.041 